Article

\title{
Can Family Members' Involvement Improve Technological Innovation? Empirical Study Based on Chinese Family-Owned Enterprises
}

\author{
Lingling Zhuang ${ }^{1}$, Lawrence Loh ${ }^{2,3}$ and Minna Zheng ${ }^{1, *(1)}$ \\ 1 Business School, Nankai University, Tianjin 300071, China; linglingzhuang@mail.nankai.edu.cn \\ 2 Centre for Governance, Institutions and Organisations, National University of Singapore, \\ Singapore 117592, Singapore; bizlohyk@nus.edu.sg \\ 3 Department of Strategy and Policy, Business School, National University of Singapore, \\ Singapore 119245, Singapore \\ * Correspondence: zhengmn1991@163.com
}

Received: 29 October 2020; Accepted: 10 December 2020; Published: 15 December 2020

\begin{abstract}
From the perspective of agency theory, family members' involvement is negatively correlated with technological innovation. However, from the perspective of stewardship theory, it is believed that family members' involvement is positively correlated with technological innovation. From the phenomenon mentioned above, this paper studies the influence of family members' involvement on R\&D investment and R\&D output and tests the above competitive hypotheses. Based on the 2007-2016 data of A-share listed family-owned enterprises, this empirical study found that family members involved in corporate management not only save R\&D investment, but they also increase R\&D output. After controlling for endogeneity, the above conclusions are still valid. This study provides empirical evidence for the objective recognition of the relationship between family members' involvement and technological innovation.
\end{abstract}

Keywords: family members' involvement; agency; stewardship; R\&D investment; R\&D output

\section{Introduction}

After more than 40 years of reform and opening up, China's private economy, especially family-owned enterprises, has emerged in the global competition and has gradually become a force that cannot be ignored in China's economic development. After China's economy entered the "new normal", improving the R\&D capabilities of publicly listed firms has become an important way to transform the economic development model. Family-owned enterprises also have to choose a technological innovation management model. Combined with the relevant academic research, there are two patterns at present [1,2]. The first model is that family members hold shares through trust funds and no longer participate in the operation and management of the company. Professional managers are responsible for formulating the company's competitive strategy. For example, the Watson family gradually withdrew from IBM's board of directors in the 1970s. The second model is that family members do not give up the control of the company and participate in the strategic planning and business decision-making. According to the current materials found by the authors, family-owned enterprises in developed countries in America and Europe generally prefer the second model [1]. However, there are significant differences between China's institutional culture and those of developed countries in America and Europe, so it is necessary to find an appropriate management model to enhance the technological competitiveness of the company.

Generally speaking, family involvement in management affects the technological innovation of family-owned enterprises [3,4]. According to the existing literature and research, the influence 
of family involvement on technological innovation mainly focuses on $R \& D$ investment and R\&D output $[5,6]$. However, there is no unified conclusion on whether family members' involvement has a positive or negative impact on technological innovation. Most studies suggest that family members' involvement is negatively correlated with R\&D investment $[7,8]$. However, there is no consistent view on family members' involvement and R\&D output $[9,10]$. In order to enrich the research gap in this field, this paper studies the relationship between family members' involvement and technological innovation from perspective of Chinese family-owned enterprises.

The choice of a management model is closely related to the assumption of human nature [11]. If we focus on the innovation management model selection of family-owned enterprises, we may obtain research hypotheses that are the opposite of those from agency and stewardship theory. In order to test the applicability and explanatory power of the above two theories, this article conducts research from the most obvious altruistic perspective that distinguishes family-owned enterprises from nonfamily enterprises and demonstrates that family members' involvement influences the technological innovation of family-owned enterprises.

The research results of this paper show that family members' involvement in management not only saves R\&D investment, but it also increases R\&D output, which indicates that stewardship theory is supported by empirical evidence. Compared with previous studies, this study has the following contributions. Firstly, this paper deduces competitive hypothesis from agency theory and stewardship theory by analyzing how family members' involvement affects technological innovation of family-owned enterprises, and it empirically tests applicability and explanatory power of the two theories. Secondly, how to build a lasting family business is an important issue that concerns many Chinese private enterprises. With respect to innovation model selection, this article explores a management model suitable for the technological innovation of Chinese family-owned enterprises. Finally, the research conclusions of this paper are of practical significance and enrich academic research on innovation activities of family-owned enterprises.

The article contents are arranged as follows. The first part discusses the theoretical basis and research hypotheses. The second part describes the research methods. The third part reports the empirical test results. The fourth part is the robustness test. The final part is the research summary.

\section{Theoretical Basis and Research Hypotheses}

\subsection{Theoretical Basis}

Jensen and Meckling [12] proposed agency theory in the 1970s. The establishment of a modern company system separates the ownership and management of companies, leading to the generation of agency costs. The relationship between the principal and the agent is actually a contractual relationship. Due to the weak investor protection environment in the capital market and the lack of necessary supervision of publicly listed firms, the agent will use the wealth of the principal, namely, the company's resources, for on-the-job consumption. According to principal-principal agency theory [13], the interests of controlling family members and minority shareholders are inconsistent [14]. The controlling family members have their eyes on family's own interests rather than the overall development of family-owned enterprises which can damage firms' market value [15]. Such behaviors will lead to the waste of resources, such as excessive R\&D investment and less R\&D output.

Stewardship theory puts forward different views on the influence of family members' involvement on technological innovation [16]. From the reference above, we found that family members are more like stewards who manage the family business, because they desire the longevity of the family business. As stewards, family members are actively responsible for the development of family business [17] and the successful succession of the next generation [18], which is beneficial for technological innovation. By analyzing the previous literature, we find that there is no certain conclusion on the theory applicable to technological innovation in family-owned enterprises. 


\subsection{Research Hypotheses}

A family-owned enterprise is a special economic organization. The management model of family-owned enterprises is very different from that of nonfamily enterprises. At present, there are two common models [1,2]. The first model is that family members hold shares through trust funds and no longer participate in the company's business management. Professional managers are responsible for formulating the company's competitive strategy [2]. The second model is that family members do not give up control of the company and participate in the strategic planning and operational decisions. An appropriate management model is conducive to the construction of the core competence of family-owned enterprises. However, the management model of Chinese family-owned enterprises has the characteristics of combining "rationality" and "sensibility". Therefore, finding a management model suitable for the technological innovation of Chinese family-owned enterprises is a practical problem that urgently needs to be solved.

A family consists of a group of relatives, including blood relatives, in-laws, and members with adoptive relationships. Kindred relationships cover a wide range of people, and family members are the main people in charge of family affairs and the sequential heirs of the property [19]. Altruism, which is an irrational behavioral preference of family members, generally exists in family-owned enterprises [20]. Under the influence of altruism, the personal interests of family members and the interests of family-owned enterprises tend to be consistent [21], reducing the agency problem between the principals and family agents [22].

Technological innovation is a long-term investment activity that requires rigorous strategic planning. In the absence of external supervision, management is prone to laziness and shirking [23] while altruism alleviates such opportunistic behaviors. Thus, family members serving as executives help to reduce agency costs [24]. In addition, Bauweraerts et al. [25] believe that a certain number of family members serving on the board of directors is conducive to the entrepreneurial development of family-owned enterprises. Therefore, the personal interests of family members and the interests of the family business are naturally consistent. Thus, family members are not willing to invest the family capital in high-risk $R \& D$ projects and tend to save $R \& D$ investment. The embeddedness of altruism reduces the supervision costs between the principals and the family agents [26] and results in higher $R \& D$ performance. Based on the above analysis, this paper proposes the following hypotheses:

Hypothesis 1a (H1a). The involvement of family members is negatively correlated with RED investment. The specific performances are as follows: (1) When the actual controller is related to the directors, supervisors and executives, family-owned enterprises tend to save RED investment. (2) Compared with nonfamily members serving as CEOs, family-owned enterprises tend to save RED investment when family members serve as CEOs. (3) As the number of family members on the board of directors increases, family-owned enterprises tend to save RED investment.

Hypothesis 2a (H2a). The involvement of family members is positively correlated with RED performance. The specific performances are as follows: (1) The RED output of family-owned enterprises is higher when the actual controller is related to the directors, supervisors, and executives. (2) Compared with nonfamily members serving as CEOs, the RED output of family-owned enterprises is higher when family members serve as CEOs. (3) As the number of family members on the board of directors increases, the RED output of family-owned enterprises increases.

Altruistic behavior is a double-edged sword that not only benefits the development of family-owned enterprises, but it also negatively influences the governance of family-owned enterprises. Firstly, the existence of altruistic behavior has led to a lack of supervision of family members. The assessment of the family members does not follow the prescribed salary assessment mechanism [27], which will cause the family members to lose restraint, resulting in excessive resource waste in family-owned enterprises. Secondly, there is a diversity-orderly structure in the kindred relationship 
of family-owned enterprises [28], which makes altruistic behavior show certain differences among different family members. Altruism is more obvious in core family members and close relatives than in distant relatives [29]. These differences caused by altruism will increase the sense of internal imbalance among family members and aggravate the internal contradictions of family-owned enterprises [30], which will have a negative impact on innovation activities. Lastly, the existence of altruistic behavior in family-owned enterprises facilitates "free-riding" behavior. Even if the family members are not competent enough, the possibility of family members being dismissed is very small. The phenomenon of cronyism further aggravates the internal contradictions of family-owned enterprises. The loose supervision mechanism of family members, the conflicts among family members and the negative behavior of cronyism will lead to excessive resource waste in family-owned enterprises. However, innovation is an enterprise activity that needs sufficient resources, and family-owned enterprises must make excessive R\&D investments to compensate for the wasted resources.

When family members participate in the governance of family business, the family-owned enterprises show poor performance [31]. Furthermore, it is found that core family members are conducive to improving business performance, close relatives have a certain negative effect on business performance, and distant relatives have an uncertain impact on business performance [32]. Therefore, the founders of family enterprises tend to choose professional managers rather than the descendants of family enterprises when selecting successors. For example, Zhang Zhongmou, chairman of Taiwan Semiconductor Manufacturing Company Limited, announced his retirement in June 2018 with professional manager Liu Deyin taking over as the chairman of the company. Through the above analysis, we find that the involvement of family members in business activities is not conducive to improving the performance of publicly listed firms. However, technological innovation is an investment activity with high investment, high risk and long-term investment. Poor corporate performance is not conducive to providing capital for R\&D activities, which will further lead to poor $R \& D$ performance. Based on the above analysis, this paper proposes the following hypotheses:

Hypothesis $\mathbf{1 b} \mathbf{( H 1 b ) . ~ T h e ~ i n v o l v e m e n t ~ o f ~ f a m i l y ~ m e m b e r s ~ i s ~ p o s i t i v e l y ~ c o r r e l a t e d ~ w i t h ~ R E D ~ i n v e s t m e n t . ~}$ The specific performances are as follows: (1) The RED investment is higher when the actual controller is related to the directors, supervisors, and executives. (2) Compared with nonfamily members serving as CEOs, the RED investment is higher when family members serve as CEOs. (3) As the number of family members on the board of directors increases, RED investment increases.

Hypothesis $\mathbf{2 b} \mathbf{( H 2 b )}$. The involvement of family members is negatively correlated with RED performance. The specific performance is as follows: (1) The RED output of family-owned enterprises is lower when the actual controller is related to the directors, supervisors, and executives. (2) Compared with nonfamily members serving as CEOs, the RED output of family-owned enterprises is lower when family-owned enterprise members serve as CEOs. (3) As the number of family members on the board of directors increases, the RED output of family-owned enterprises decreases.

\section{Sample Selection and Research Methods}

\subsection{Sample Selection}

This paper uses the family-owned enterprises listed in the A-share market from 2007 to 2016 as the research object. The starting point of the sample study is 2007, which is when publicly listed firms in China began to disclose their R\&D investment. This study follows the definition of family-owned enterprises by $\mathrm{Xu}$ et al. [33] and Jiang et al. [34], including the following aspects: (1) The control power of publicly listed firms can be attributed to a natural person or a family. (2) Natural persons or families directly or indirectly hold $20 \%$ or more of the equity of the listed company. (3) The ultimate controller is directly or indirectly the largest shareholder of the listed company. After satisfying the above conditions, we excluded the publicly listed firms that were delisted. Furthermore, we excluded the missing observation data due to lack of disclosure by publicly listed firms. The final number of 
sample observations was 7541. Except for the independent variables collected manually, the rest of the data came from the China Stock Market \& Accounting Research database.

\subsection{Definition of Variables}

The measurement of family members' involvement. We use the securities codes of the family-owned enterprises listed on the Shanghai and Shenzhen stock exchanges from 2007 to 2016. The data on the independent variables are manually obtained from the information that senior management disclosed in their prospectuses and annual reports. We use the resumes of senior executives in the Sina Finance and China Stock Market \& Accounting Research databases. Following the research of Gu et al. [35] and Yan et al. [36], the independent variables in this paper are defined as follows: (1) Kindred relationship between the actual controller and directors, supervisors, or executives. (2) Whether the CEO is a family member. (3) Total number of relatives.

The measurement of technological innovation. This study follows Tian et al. [37], Zhou et al. [38] and Kong et al. [39] by using R\&D investment and R\&D output as proxy variables for technological innovation. $R \& D$ investment is expressed by dividing $R \& D$ expenditures by total assets. $R \& D$ output is expressed as the logarithm of the number of patent applications. The number of patent applications is the sum of the applied invention patents, utility model patents and design patents. The measurement of the control variables is shown in Table 1.

\subsection{Model Design}

This paper uses the data of A-share listed family-owned enterprises, and the total number of sample observations was 7541 . Only 1379 samples, accounting for only $18 \%$ of the total sample, disclosed R\&D investment, and 6162 samples did not disclose R\&D investment. Regarding R\&D output, 5393 samples, accounting for $72 \%$ of the total sample, disclosed R\&D output, and 2148 samples did not disclose $R \& D$ output. There are a large number of 0 samples in the dependent variables, which do not conform to a normal distribution. A biased estimation will be generated when the least square method is used. Therefore, the tobit model was adopted in this study to conduct the regression.

The empirical test of this paper is divided into two parts: (1) The impact of family members' involvement on R\&D investment. (2) The impact of family members' involvement on R\&D output. In order to carry out the above tests, the following regression models were constructed:

innovation $=\alpha+\beta_{1}{ }^{*}$ relation $+\Sigma \gamma_{\mathrm{i}}{ }^{*}$ controls $_{\mathrm{i}}+\varepsilon_{1}$,

innovation $=\alpha+\beta_{1}{ }^{*}$ fceo $+\Sigma \gamma_{\mathrm{i}}{ }^{*}$ controls $_{\mathrm{i}}+\varepsilon_{2}$, and

innovation $=\alpha+\beta_{1}{ }^{*}$ relatives $+\Sigma \gamma_{\mathrm{i}}{ }^{*}$ controls $_{\mathrm{i}}+\varepsilon_{3}$.

Among the variables, the innovation variable is represented by $R \& D$ investment and $R \& D$ output, and the symbols are rd_ratio and patent_app, respectively. Relation indicates whether there is a kindred relationship between the actual controller and director. Fceo indicates whether the CEO comes from the actual controller's family. Relatives indicates the total number of relatives. Among the control variables, fam_share represents the ratio of family shareholding, found_share represents the ratio of fund shareholding, size represents the firm size, age represents the firm age, roa represents the return on assets, lev represents the asset-liability ratio, tobinq represents market value, board represents board size, board_ind represents board independence, patent_expire represents the number of expired patents, index represents the urban innovation index [40], industry represents the industry dummy variable, year represents the year dummy variable, and $\varepsilon$ represents a random disturbance term.

Table 3 reports the correlation coefficients between independent variables and control variables. From the results in Table 3, it can be concluded that there is a certain correlation among the independent variables, which may cause the problem of multicollinearity. However, the three independent variables in this study are in different regression models; thus, multicollinearity has no effect on this study. 
Table 1. Variables.

\begin{tabular}{|c|c|c|}
\hline Symbol & Variable & Definition \\
\hline \multicolumn{3}{|c|}{ Dependent variables } \\
\hline rd_ratio & R\&D investment & R\&D expenditures divided by total assets * 100 \\
\hline patent_app & R\&D output & The logarithm of the sum of the applied invention patents, utility model patents and design patents \\
\hline \multicolumn{3}{|c|}{ Independent variables } \\
\hline relation & $\begin{array}{l}\text { Kindred relationship between actual controller and } \\
\text { directors, supervisors, or executives }\end{array}$ & $\begin{array}{l}\text { If there is a kindred relationship between the actual controller and director, supervisor, or senior } \\
\text { executives, then we mark it as } 1 \text {, otherwise we mark it as } 0\end{array}$ \\
\hline fceo & Whether the CEO is a family member & If the CEO comes from the actual controller's family, then we mark it as 1 , otherwise we mark it as 0 \\
\hline relatives & Total number of relatives & Add 1 to the number of board members related to the actual controller, and then take a logarithm of $i$ \\
\hline \multicolumn{3}{|l|}{ Control variables } \\
\hline fam_share & Ratio of family shareholding & Number of family shareholding divided by the total share capital \\
\hline found_share & Ratio of fund shareholding & Number of fund holdings divided by total share capital \\
\hline size & Firm size & The logarithm of total assets at the end of the year \\
\hline age & Firm age & $\begin{array}{c}\text { Add } 1 \text { to the difference between the observation year and the establishment year of the enterprises, } \\
\text { and then take a logarithm of it }\end{array}$ \\
\hline roa & Return on assets & Earnings before interest and tax divided by total assets \\
\hline lev & Asset-liability ratio & Total liabilities divided by total assets \\
\hline tobinq & Tobin's Q ratio & Market value divided by replacement cost \\
\hline board & Board size & The logarithm of the total number of board members \\
\hline board_ind & Board independence & The number of independent directors divided by the total number of board members \\
\hline patent_expire & Expired patent & $\begin{array}{l}\text { The logarithm of the difference between the number of patent applications terminated and the number } \\
\text { of patents that have been authorized to terminate by the current year }\end{array}$ \\
\hline index & Urban innovation index & The matching between registered address of publicly listed firms and urban innovation index \\
\hline industry & Industry variables & Industry dummy variables \\
\hline year & Year variables & Year dummy variables \\
\hline
\end{tabular}




\section{Empirical Research}

\subsection{Descriptive Statistics and Correlation Analysis}

Table 2 shows the results of descriptive statistics for the full sample. In the dependent variable, the mean value of rd_ratio was 0.2038 , indicating that the mean R\&D investment per 100 yuan of assets in the sample company was 0.2038 yuan. The mean value of patent_app was 1.7767 , indicating that the mean number of patent applications in sample companies was 4.91. The maximum value of patent_app was 7.2584, indicating that the maximum number of patent applications among the sample companies was 1419, which corresponded to the total number of patent applications of Joyoung (stock code 002242) in 2016. It was found that the number of patent applications of each listed company in the full sample fluctuated greatly. Among the independent variables, the mean value of the dummy variable relation was 0.3860 , indicating that the samples with kindred relationships accounted for $38.6 \%$ of the total sample. The mean value of the dummy variable fceo was 0.2705 , indicating that the sample of publicly listed firms with family members as CEOs accounted for $27.05 \%$ of the total sample. The mean of the variable relatives was 0.4647 , indicating that the mean number of family members on the board of directors of the sample companies was 0.60 . The maximum value of relatives was 1.9459 , indicating that the maximum number of family members on the board of directors of a sample company was 6. According to information disclosed by the publicly listed firms, both SF Diamond (stock code 300179) and XingMin ITS (stock code 002355) have six family members serving on their respective board of directors.

Table 2. Descriptive statistics.

\begin{tabular}{cccccc}
\hline Variables & Observations & Mean & SD & Min & Max \\
\hline rd_ratio & 7541 & 0.2038 & 0.8474 & 0.0000 & 23.2558 \\
patent_app & 7541 & 1.7767 & 1.4757 & 0.0000 & 7.2584 \\
success_ratio & 7541 & 0.6181 & 0.3862 & 0.0000 & 1.0000 \\
relation & 7541 & 0.3860 & 0.4869 & 0.0000 & 1.0000 \\
fceo & 7541 & 0.2705 & 0.4443 & 0.0000 & 1.0000 \\
relatives & 7541 & 0.4647 & 0.6068 & 0.0000 & 1.9459 \\
fam_share & 7541 & 0.3957 & 0.1298 & 0.2000 & 0.8649 \\
fund_share & 7541 & 0.0400 & 0.0585 & 0.0000 & 0.5129 \\
tobinq & 7541 & 3.3819 & 2.4078 & 0.6831 & 31.5647 \\
roa & 7541 & 0.0526 & 0.0507 & -0.6464 & 0.4819 \\
lev & 7541 & 0.3467 & 0.1970 & 0.0075 & 1.5672 \\
size & 7541 & 21.4641 & 0.9824 & 18.2194 & 26.2443 \\
age & 7541 & 2.4780 & 0.4731 & 0.0000 & 3.6109 \\
board & 7541 & 2.1015 & 0.1856 & 1.3863 & 2.8904 \\
board_ind & 7541 & 0.3755 & 0.0541 & 0.2000 & 0.6667 \\
patent_expire & 7541 & 0.6076 & 1.0585 & 0.0000 & 5.8999 \\
index & 7541 & 130.4392 & 218.0992 & 0.0100 & 1061.3700 \\
\hline
\end{tabular}

\subsection{Regression Results}

Table 4 reports the regression results. The results of column 1 to column 3 show the impact of family members' involvement on rd_ratio. In column 1, the regression coefficient is -0.4011 and significant at the $1 \%$ level, indicating that the R\&D investment is lower when there is a kindred relationship between the actual controller and director, supervisor or senior executives. In column 2 , the regression coefficient is negative and significant at the $1 \%$ level (coefficient $=-0.4448, p<0.01$ ), which shows that compared with non-family members serving as CEO, the R\&D investment is lower when family members serve as CEO. In column 3 , the regression coefficient is -0.3654 and significant at the $1 \%$ level. The result suggests that with the increase in the number of family members on the board of directors, the R\&D investment decreases. In total, the three independent variables are all negatively related to rd_ratio, indicating that the involvement of family members will save R\&D investment. 
Table 3. Pearson correlations.

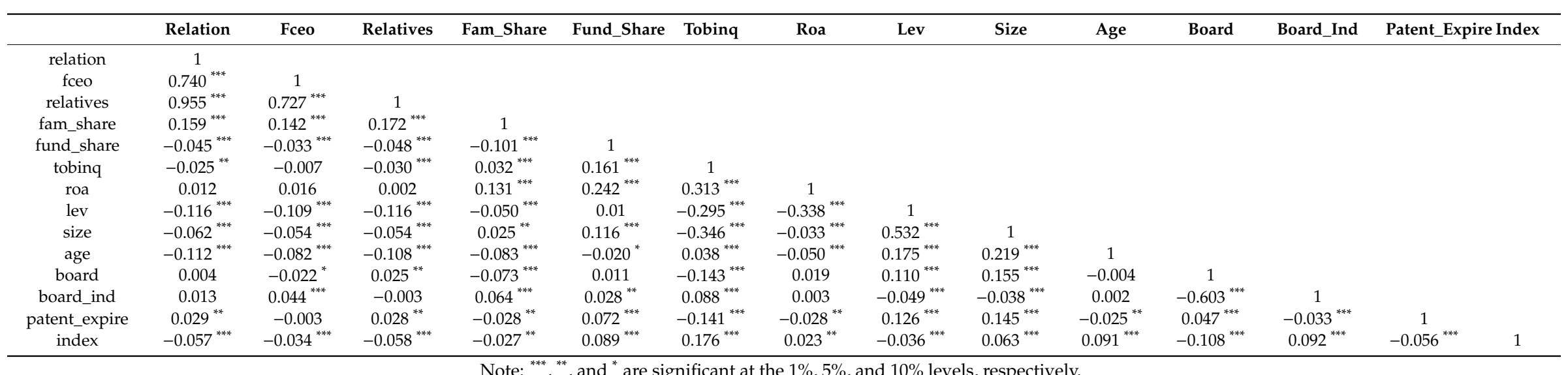

Note: ${ }^{* * *},{ }^{* *}$, and $^{*}$ are significant at the $1 \%, 5 \%$, and $10 \%$ levels, respectively. 
Table 4. Regression results of family members' involvement and technological innovation.

\begin{tabular}{|c|c|c|c|c|c|c|}
\hline & $\stackrel{(1)}{R d \_ \text {Ratio }}$ & $\stackrel{(2)}{R d \_R a t i o}$ & $\stackrel{\text { (3) }}{\text { Rd_Ratio }}$ & $\begin{array}{c}\text { (4) } \\
\text { Patent_App }\end{array}$ & $\begin{array}{c}\text { (5) } \\
\text { Patent_App }\end{array}$ & $\begin{array}{c}\text { (6) } \\
\text { Patent_App }\end{array}$ \\
\hline relation & $\begin{array}{c}-0.4011^{* * *} \\
(-4.68)\end{array}$ & & & $\begin{array}{c}0.2858^{* * *} \\
(7.08)\end{array}$ & & \\
\hline fceo & & $\begin{array}{c}-0.4448^{* * *} \\
(-4.68)\end{array}$ & & & $\begin{array}{c}0.1499^{* * *} \\
(3.44)\end{array}$ & \\
\hline relatives & & & $\begin{array}{c}-0.3654^{* * *} \\
(-5.23)\end{array}$ & & & $\begin{array}{c}0.2210^{* * *} \\
(6.83)\end{array}$ \\
\hline fam_share & $\begin{array}{c}-1.4351^{* * *} \\
(-4.46)\end{array}$ & $\begin{array}{c}-1.4624^{* * *} \\
(-4.54)\end{array}$ & $\begin{array}{c}-1.3808^{* * *} \\
(-4.28)\end{array}$ & $\begin{array}{c}0.4586^{* * *} \\
(2.91)\end{array}$ & $\begin{array}{c}0.5593^{* * *} \\
(3.55)\end{array}$ & $\begin{array}{c}0.4451^{* * *} \\
(2.82)\end{array}$ \\
\hline fund_share & $\begin{array}{c}4.5026^{* * *} \\
(6.75)\end{array}$ & $\begin{array}{c}4.5065^{* * *} \\
(6.74)\end{array}$ & $\begin{array}{c}4.4947^{* * *} \\
(6.74)\end{array}$ & $\begin{array}{c}1.4778^{* * *} \\
(4.16)\end{array}$ & $\begin{array}{c}1.4852^{* * *} \\
(4.17)\end{array}$ & $\begin{array}{c}1.4794^{* * *} \\
(4.17)\end{array}$ \\
\hline tobinq & $\begin{array}{c}0.1529^{* * *} \\
(7.17)\end{array}$ & $\begin{array}{c}0.1535^{* * *} \\
(7.19)\end{array}$ & $\begin{array}{c}0.1532^{* * *} \\
(7.19)\end{array}$ & $\begin{array}{c}-0.0592^{* * *} \\
(-4.99)\end{array}$ & $\begin{array}{c}-0.0619^{* * *} \\
(-5.22)\end{array}$ & $\begin{array}{c}-0.0597^{* * *} \\
(-5.04)\end{array}$ \\
\hline roa & $\begin{array}{c}-5.7379^{* * *} \\
(-6.46)\end{array}$ & $\begin{array}{c}-5.7144^{* * *} \\
(-6.43)\end{array}$ & $\begin{array}{c}-5.8147^{* * *} \\
(-6.55)\end{array}$ & $\begin{array}{c}2.9706^{* * *} \\
(6.39)\end{array}$ & $\begin{array}{c}2.9520^{* * *} \\
(6.33)\end{array}$ & $\begin{array}{c}3.0267^{* * *} \\
(6.50)\end{array}$ \\
\hline lev & $\begin{array}{c}-1.8925^{* * *} \\
(-6.76)\end{array}$ & $\begin{array}{c}-1.9089^{* * *} \\
(-6.80)\end{array}$ & $\begin{array}{c}-1.9099^{* * *} \\
(-6.81)\end{array}$ & $\begin{array}{c}-0.4665^{* * *} \\
(-3.34)\end{array}$ & $\begin{array}{c}-0.4886^{* * *} \\
(-3.49)\end{array}$ & $\begin{array}{c}-0.4577^{* * *} \\
(-3.28)\end{array}$ \\
\hline size & $\begin{array}{c}0.4988^{* * *} \\
(8.38)\end{array}$ & $\begin{array}{c}0.5042^{* * *} \\
(8.46)\end{array}$ & $\begin{array}{c}0.5044^{* * *} \\
(8.48)\end{array}$ & $\begin{array}{l}0.0476 \\
(1.56)\end{array}$ & $\begin{array}{c}0.0410 \\
(1.34)\end{array}$ & $\begin{array}{c}0.0445 \\
(1.46)\end{array}$ \\
\hline age & $\begin{array}{c}-0.2683^{* * *} \\
(-2.83)\end{array}$ & $\begin{array}{c}-0.2530^{* * *} \\
(-2.68)\end{array}$ & $\begin{array}{c}-0.2746^{* * *} \\
(-2.90)\end{array}$ & $\begin{array}{c}-0.3758^{* * *} \\
(-8.12)\end{array}$ & $\begin{array}{c}-0.3938^{* * *} \\
(-8.51)\end{array}$ & $\begin{array}{c}-0.3789^{* * *} \\
(-8.19)\end{array}$ \\
\hline board & $\begin{array}{c}-0.5258^{* *} \\
(-1.97)\end{array}$ & $\begin{array}{c}-0.5691 \\
(-2.14)\end{array}$ & $\begin{array}{c}-0.5083^{*} \\
(-1.91)\end{array}$ & $\begin{array}{c}0.4982^{* * *} \\
(3.67)\end{array}$ & $\begin{array}{l}0.5236^{* * *} \\
(3.85)\end{array}$ & $\begin{array}{c}0.4848^{* * *} \\
(3.57)\end{array}$ \\
\hline board_ind & $\begin{array}{c}0.5162 \\
(0.58)\end{array}$ & $\begin{array}{c}0.5354 \\
(0.60)\end{array}$ & $\begin{array}{c}0.5018 \\
(0.56)\end{array}$ & $\begin{array}{c}0.8014 \\
(1.79)\end{array}$ & $\begin{array}{c}0.8230^{*} \\
(1.83)\end{array}$ & $\begin{array}{c}0.8211^{*} \\
(1.83)\end{array}$ \\
\hline patent_expire & $\begin{array}{c}-0.0339 \\
(-0.86)\end{array}$ & $\begin{array}{c}-0.0392 \\
(-1.00)\end{array}$ & $\begin{array}{c}-0.0321 \\
(-0.82)\end{array}$ & $\begin{array}{c}0.5970^{* * *} \\
(32.17)\end{array}$ & $\begin{array}{c}0.6000^{* * *} \\
(32.24)\end{array}$ & $\begin{array}{c}0.5974^{* * *} \\
(32.18)\end{array}$ \\
\hline index & $\begin{array}{c}0.0017^{* * *} \\
(9.19)\end{array}$ & $\begin{array}{c}0.0017^{* * *} \\
(9.28)\end{array}$ & $\begin{array}{c}0.0017^{* * *} \\
(9.20)\end{array}$ & $\begin{array}{c}0.0004^{* * *} \\
(3.76)\end{array}$ & $\begin{array}{c}0.0003^{* * *} \\
(3.57)\end{array}$ & $\begin{array}{c}0.0004^{* * *} \\
(3.74)\end{array}$ \\
\hline $\begin{array}{l}\text { industry } \\
\text { year }\end{array}$ & \multicolumn{6}{|c|}{$\begin{array}{l}\text { control } \\
\text { control }\end{array}$} \\
\hline _cons & $\begin{array}{c}-11.0534^{* * *} \\
(-7.70)\end{array}$ & $\begin{array}{c}-11.1167^{* * *} \\
(-7.74)\end{array}$ & $\begin{array}{c}-11.1903^{* * *} \\
(-7.80)\end{array}$ & $\begin{array}{c}-2.4703^{* * *} \\
(-3.37)\end{array}$ & $\begin{array}{c}-2.3252^{* * *} \\
(-3.17)\end{array}$ & $\begin{array}{c}-2.3713^{* * *} \\
(-3.24)\end{array}$ \\
\hline pseudo $R^{2}$ & 0.072 & 0.072 & 0.072 & 0.126 & 0.125 & 0.126 \\
\hline chi2 & $787.2786^{* * *}$ & $787.5989^{* * *}$ & $792.9970^{* * *}$ & $3380.1502^{* * *}$ & $3341.9518^{* * *}$ & $3376.6842^{* * *}$ \\
\hline$N$ & 7541 & 7541 & 7541 & 7541 & 7541 & 7541 \\
\hline
\end{tabular}

Note: ${ }^{* * *}, * *$, and ${ }^{*}$ are significant at the $1 \%, 5 \%$, and $10 \%$ levels, respectively. 
The results of column 4 to column 6 show the impact of family members' involvement on patent_app. In column 4, the regression coefficient is 0.2858 and significant at the $1 \%$ level, indicating that the amount of patent_app is higher when there is a kindred relationship between the actual controller and director, supervisor, or senior executives. In column 5, the regression coefficient is positive and significant at the $1 \%$ level (coefficient $=0.1499, p<0.01$ ), which shows that compared with non-family members serving as CEO, the amount of patent_app is higher when family members serve as CEO. In column 6, the regression coefficient is 0.2210 and significant at the $1 \%$ level. The result suggests that with the increase in the number of family members on board of directors, the amount of patent_app increases. In total, the three independent variables are all positively related to patent_app, indicating that the involvement of family members will improve the amount of patent_app. The above research results indicate that family members' involvement not only saves R\&D investment, but it also increases R\&D output.

Based on the discussion of the theory in this paper, we find that family members' involvement in the management of a company not only strengthens the effective supervision of the company, but it also improves the operating efficiency of the company. Regarding technological innovation, under the influence of altruism, the agency costs within the family business are reduced, and the involvement of family members saves $R \& D$ investment and improves $R \& D$ performance [6]. The research results of this paper are consistent with stewardship theory. Therefore, the R\&D activities of family-owned enterprises are more supportive of stewardship theory.

Finally, the regression results of the control variables show that the ratio of family shareholding is negatively correlated with R\&D investment and positively correlated with R\&D output, indicating that family shareholding not only has a supervisory role for technological innovation, but it also has an incentive effect. The ratio of fund shareholding is not only positively correlated with R\&D investment, but it is also positively correlated with R\&D output, indicating that institutional investors only play an incentive role in technological innovation. This is consistent with the conclusion of Aghion [41]. Firm age has a negative relationship with $R \& D$ investment and $R \& D$ output, indicating that $R \& D$ capability declines with the age of enterprises. Board size is negatively correlated with R\&D investment and positively correlated with R\&D output, which is consistent with the prediction of stewardship theory. However, the relationship between board independence and technological innovation is not significant, which shows that independent directors in Chinese family-owned enterprises do not play a supervisory role in technological innovation. In the study of United States publicly listed firms, board independence has a positive impact on technological innovation [42]. The results show that expired patents have no impact on technological innovation, but the accumulated R\&D experience of expired patents has a favorable impact on R\&D output. The urban innovation index is positively correlated with technological innovation, indicating that the external environment will affect R\&D activities, and subsequent research should focus on this finding.

In conclusion, it can be seen that the involvement of family members significantly saves R\&D investment and improves R\&D output. Therefore, it can be concluded from the above empirical results that hypotheses H1a and $\mathrm{H} 2 \mathrm{a}$ are verified, and the corresponding hypotheses $\mathrm{H} 1 \mathrm{~b}$ and $\mathrm{H} 2 \mathrm{~b}$ are rejected. This indicates that the research results of this paper support stewardship theory in the technological innovation activities of family-owned enterprises.

\section{Robustness Test}

In this paper, the following three aspects were tested for robustness. Firstly, considering the possible measurement error of the independent variable and dependent variable, the variable substitution method was selected for the robustness test. Secondly, the number of patent applications is an integer. In order to ensure the unbiasedness of the research results, the Poisson model was used to conduct a further regression. Finally, we tested the endogeneity and sample selectivity biases. 


\subsection{Tests for Measurement Error}

Firstly, the number of relatives is represented by the number of family directors divided by the total number of board members, which is denoted as relatives_ratio. Secondly, R\&D investment is represented by development expenditures divided by operating income, which is denoted as rd_ratio_income. R\&D output is represented by the number of patents authorized, which is denoted as patent_aut. The number of patents authorized is the sum of the numbers of authorized invention patents, authorized utility model patents and authorized design patents. Finally, the descriptive statistics show that the minimum number of patent applications is 0 and the maximum number is 1419 , which indicates that the number of patent applications in sample companies is relatively discrete. Besides the tobit model, this paper also uses the Poisson model to conduct a regression.

Table 5 reports the results of the robustness tests of the independent variables, Table 6 reports the results of the robustness test of the dependent variables, and Table 7 reports the results of the Poisson regression robustness test. The results of the above robustness tests are consistent with the previous research results, indicating that the research conclusions of this paper are reliable.

Table 5. Robustness test of independent variables.

\begin{tabular}{|c|c|c|}
\hline & $\stackrel{(1)}{\text { Rd_Ratio }}$ & $\begin{array}{c}(2) \\
\text { Patent_App }\end{array}$ \\
\hline relatives_ratio & $\begin{array}{c}-1.5675^{* * *} \\
(-5.80)\end{array}$ & $\begin{array}{l}0.7771^{* * *} \\
(6.29)\end{array}$ \\
\hline fam_share & $\begin{array}{c}-1.3493^{* * *} \\
(-4.18)\end{array}$ & $\begin{array}{l}0.4577^{* * *} \\
(2.90)\end{array}$ \\
\hline fund_share & $\begin{array}{c}4.4739^{* * *} \\
(6.71)\end{array}$ & $\begin{array}{c}1.4935^{* * *} \\
(4.20)\end{array}$ \\
\hline tobinq & $\begin{array}{l}0.1532^{* * *} \\
(7.18)\end{array}$ & $\begin{array}{c}-0.0599^{* * *} \\
(-5.05)\end{array}$ \\
\hline roa & $\begin{array}{c}-5.8472^{* * *} \\
(-6.59)\end{array}$ & $\begin{array}{c}3.0280^{* * *} \\
(6.50)\end{array}$ \\
\hline lev & $\begin{array}{c}-1.9163^{* * *} \\
(-6.84)\end{array}$ & $\begin{array}{c}-0.4591^{* * *} \\
(-3.29)\end{array}$ \\
\hline size & $\begin{array}{c}0.5075^{* * *} \\
(8.53)\end{array}$ & $\begin{array}{r}0.0425 \\
(1.40)\end{array}$ \\
\hline age & $\begin{array}{c}-0.2773^{* * *} \\
(-2.93)\end{array}$ & $\begin{array}{c}-0.3828^{* * *} \\
(-8.28)\end{array}$ \\
\hline board & $\begin{array}{c}-0.6417^{* *} \\
(-2.41)\end{array}$ & $\begin{array}{c}0.5715^{* * *} \\
(4.20)\end{array}$ \\
\hline board_ind & $\begin{array}{l}0.4973 \\
(0.56)\end{array}$ & $\begin{array}{c}0.8328^{*} \\
(1.86)\end{array}$ \\
\hline patent_expire & $\begin{array}{l}-0.0306 \\
(-0.78)\end{array}$ & $\begin{array}{c}0.5976^{* * *} \\
(32.17)\end{array}$ \\
\hline index & $0.0017^{* * *}$ & $0.0004^{* * *}$ \\
\hline $\begin{array}{l}\text { industry } \\
\text { year }\end{array}$ & \multicolumn{2}{|c|}{$\begin{array}{l}\text { control } \\
\text { control }\end{array}$} \\
\hline & $(9.20)$ & (3.73) \\
\hline _cons & $\begin{array}{c}-10.9749^{* * *} \\
(-7.65)\end{array}$ & $\begin{array}{c}-2.4961^{* * *} \\
(-3.40)\end{array}$ \\
\hline pseudo $R^{2}$ & 0.073 & 0.126 \\
\hline chi2 & 799.8393 & 3369.5974 \\
\hline$N$ & 7541 & 7541 \\
\hline
\end{tabular}


Table 6. Robustness test of dependent variables.

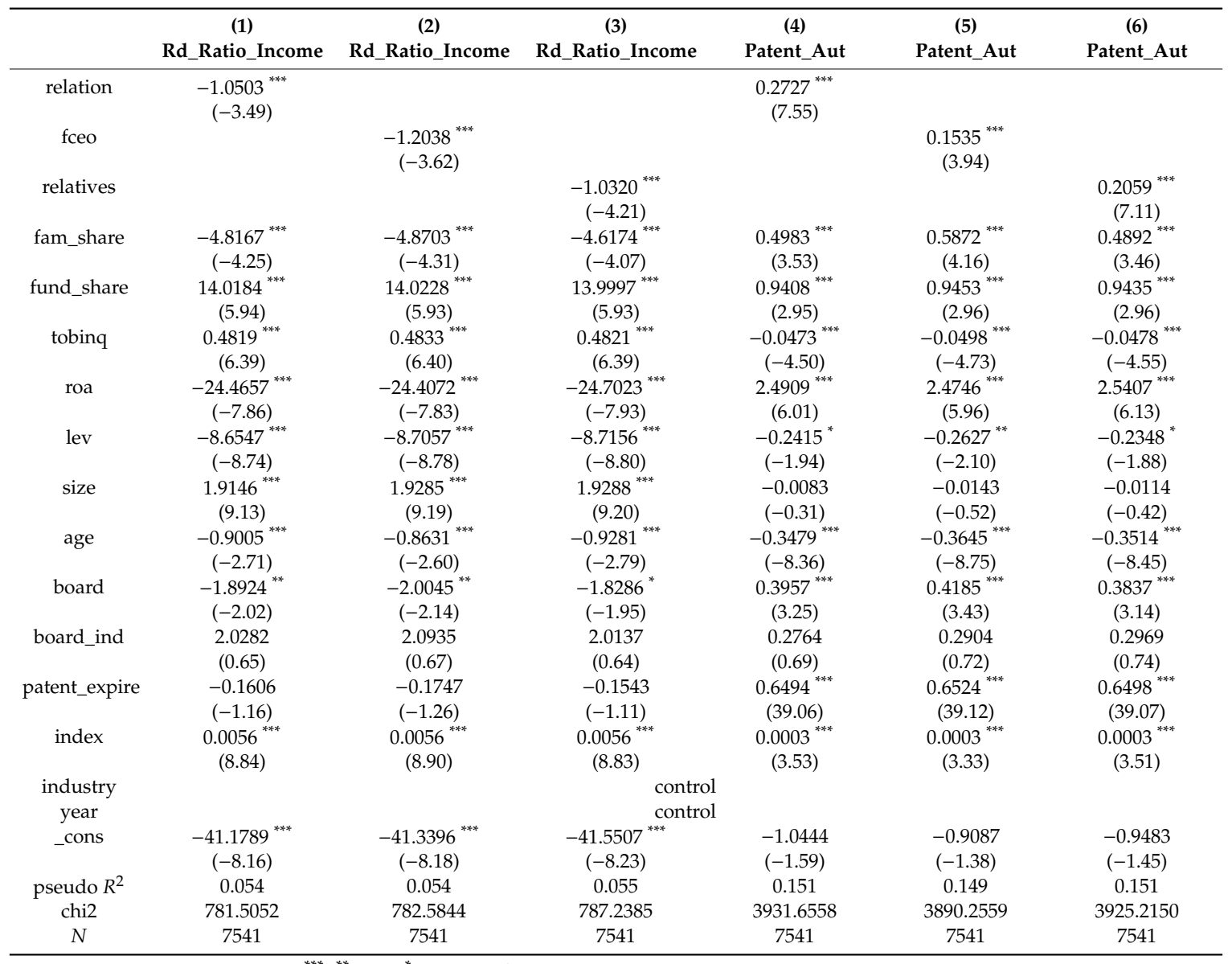

Note: ${ }^{* * *},{ }^{* *}$, and ${ }^{*}$ are significant at the $1 \%, 5 \%$, and $10 \%$ levels, respectively.

Table 7. Robustness test of Poisson regression.

\begin{tabular}{cccc}
\hline & $\begin{array}{c}\mathbf{( 1 )} \\
\text { Patent_App }\end{array}$ & $\begin{array}{c}\mathbf{( 2 )} \\
\text { Patent_App }\end{array}$ & $\begin{array}{c}\mathbf{( 3 )} \\
\text { Patent_App }\end{array}$ \\
\hline relation & $0.2843^{* * *}$ & & \\
fceo & $(4.65)$ & & \\
& & $0.2140^{* * *}$ & \\
relatives & & $(3.42)$ & \\
& & & $0.2436^{* * *}$ \\
fam_share & 0.1734 & 0.2116 & $(5.38)$ \\
fund_share & $(0.77)$ & $(0.92)$ & 0.1258 \\
& -0.4143 & -0.3804 & $(0.55)$ \\
tobinq & $(-1.01)$ & $(-0.91)$ & $(-0.4088$ \\
& 0.0136 & 0.0138 & 0.0115 \\
roa & $(0.77)$ & $(0.78)$ & $(0.64)$ \\
& $3.7037^{* * *}$ & $3.5759^{* * *}$ & $3.8552^{* * *}$ \\
lev & $(4.50)$ & $(4.26)$ & $(4.68)$ \\
& 0.2498 & 0.2589 & 0.2337 \\
size & $(1.47)$ & $(1.53)$ & $(1.36)$ \\
& $0.5117^{* * *}$ & $0.5020^{* * *}$ & $0.5089^{* * *}$ \\
age & $(8.27)$ & $(8.11)$ & $(8.16)$ \\
& $-0.39844^{* * *}$ & $-0.4124^{* * *}$ & $-0.38977^{* * *}$ \\
board & $(-5.79)$ & $(-6.10)$ & $(-5.70)$ \\
& 0.1745 & 0.2278 & 0.1847 \\
& $(0.88)$ & $(1.10)$ & $(0.97)$ \\
\hline
\end{tabular}


Table 7. Cont.

\begin{tabular}{cccc}
\hline & $\mathbf{( 1 )}$ & $\mathbf{( 2 )}$ & $\mathbf{( 3 )}$ \\
& Patent_App & Patent_App & Patent_App \\
\hline board_ind & $2.2008^{* * *}$ & $2.2808^{* * *}$ & $2.2698^{* * *}$ \\
& $(4.02)$ & $(4.03)$ & $(4.17)$ \\
patent_expire & $0.4366^{* * *}$ & $0.4398^{* * *}$ & $0.4332^{* * *}$ \\
& $(16.66)$ & $(16.54)$ & $(16.72)$ \\
index & 0.0001 & 0.0001 & 0.0001 \\
& $(0.67)$ & $(0.57)$ & $(0.59)$ \\
industry & & control & \\
year & & control & \\
cons & $-10.6461^{* * *}$ & $-10.5325^{* * *}$ & $-10.6206^{* * *}$ \\
pseudo $R^{2}$ & $(-7.90)$ & $(-7.73)$ & $(-7.85)$ \\
chi2 & 0.443 & 0.439 & 0.444 \\
$N$ & 3289.1889 & 3190.5895 & 3238.3258 \\
& 7541 & 7541 & 7541 \\
\hline \multicolumn{4}{c}{ Note: ${ }^{* * *}$ is significant at the 1\% levels, respectively. }
\end{tabular}

\subsection{Endogeneity Test}

In order to exclude the influence of sample self-selection bias on the empirical results, this paper adopts the propensity score matching method to conduct an endogeneity test. Family-owned enterprises without kindred relationships are screened out, but they are similar to those with kindred relationships. Propensity score matching is divided into two steps: (1) Use a logit model to determine whether the kindred relationship has an impact on R\&D investment. (2) Apply the nearest neighbor matching method to conduct one-to-one sample matching within the range of 0.05. (3) The above operation is repeated to verify whether the kindred relationship has an impact on R\&D output. After using the self-service method to complete the above operations, the test results in Table 8 show that the average treatment effect of the treatment group in R\&D investment is statistically significant at the $5 \%$ level, and the average treatment effect of the treatment group on R\&D output is statistically significant at the $1 \%$ level. This indicates that the research conclusions of this paper are still valid after considering the endogeneity.

Table 8. Propensity Score Matching test.

\begin{tabular}{ccc}
\hline & Rd_Ratio & Patent_App \\
\hline \multirow{2}{*}{ ATT } & $-0.0711^{* *}$ & $0.1596^{* * *}$ \\
& $(-2.47)$ & $(3.05)$ \\
ATU & -0.0136 & $0.2765^{* * *}$ \\
& $(-0.26)$ & $(4.63)$ \\
ATE & -0.0360 & $0.2308^{* * *}$ \\
& $(-0.99)$ & $(5.22)$ \\
\hline${ }^{* * * *},{ }^{* *}$ are significant at the $1 \%, 5 \%$ levels, respectively.
\end{tabular}

In order to further exclude the possible endogeneity in this paper, the two-stage least squares method is used for further testing. The instrumental variables are the number of relatives with one lag and two lags, respectively. It can be seen from the regression coefficient in Table 9 that family members' involvement in family-owned enterprises not only saves R\&D investment, but it also increases R\&D output. Therefore, the regression results of the two-stage least squares method are still robust, which can basically exclude the influence of endogeneity on the conclusions of this paper. 
Table 9. Regression results of Two-stage Least Squares.

\begin{tabular}{|c|c|c|c|c|c|c|}
\hline & \multirow{2}{*}{$\begin{array}{c}\text { First-Stage Regression } \\
\text { Relatives }\end{array}$} & \multicolumn{2}{|c|}{ Second-Stage Regression } & \multirow{2}{*}{$\begin{array}{c}\text { First-Stage Regression } \\
\text { Relatives }\end{array}$} & \multicolumn{2}{|c|}{ Second-Stage Regression } \\
\hline & & Rd_Ratio & Patent_App & & Rd_Ratio & Patent_App \\
\hline relatives_lag1 & $\begin{array}{c}0.9531^{* * *} \\
(273.97)\end{array}$ & & & & & \\
\hline relatives_lag2 & & & & $\begin{array}{c}0.9025^{* * *} \\
(162.21)\end{array}$ & & \\
\hline relatives & & $\begin{array}{c}-0.0445^{* *} \\
(-2.22)\end{array}$ & $\begin{array}{c}0.1778^{* * *} \\
(6.36)\end{array}$ & & $\begin{array}{c}-0.0611^{* *} \\
(-2.47)\end{array}$ & $\begin{array}{l}0.1906^{* * *} \\
(5.65)\end{array}$ \\
\hline control variables & & Yes & & & Yes & \\
\hline _cons & $\begin{array}{c}-0.0739 \\
(-1.01)\end{array}$ & $\begin{array}{l}-0.4116 \\
(-1.02)\end{array}$ & $\begin{array}{l}-1.2619^{* *} \\
(-2.25)\end{array}$ & $\begin{array}{l}-0.1588 \\
(-1.34)\end{array}$ & $\begin{array}{l}-0.4193 \\
(-0.89)\end{array}$ & $\begin{array}{c}-1.1821^{*} \\
(-1.83)\end{array}$ \\
\hline $\operatorname{Adj} R^{2}$ & 0.933 & 0.076 & 0.354 & 0.865 & 0.074 & 0.354 \\
\hline F value & $2328.75^{* * *}$ & $490.0859^{* * *}$ & $3288.1448^{* * *}$ & $849.50^{* * *}$ & $375.2532^{* * *}$ & $2534.2790^{* * *}$ \\
\hline N & 5986 & 5986 & 5986 & 4640 & 4640 & 4640 \\
\hline
\end{tabular}

\section{Research Conclusions}

This paper focused on how family members' involvement in family-owned enterprises affects technological innovation. Based on a review of the relevant literature, the author found that agency theory and stewardship theory make opposite inferences when explaining the relationship between family members' involvement and technological innovation. Therefore, this paper tested the explanatory abilities of the above two theories by constructing competitive hypotheses and provided valuable suggestions for enhancing the technological innovation ability of Chinese family-owned enterprises. The empirical research results show that the involvement of family members not only saves R\&D investment, but it also increases R\&D output, which is consistent with the results predicted by stewardship theory. Therefore, this study believes that the stewardship theory can better explain the $\mathrm{R} \& \mathrm{D}$ activities of family-owned enterprises, which is of great significance for promoting the theoretical research gap of technological innovation. In order to ensure that the regression results were robust, this paper eliminated the influence of measurement errors by substituting independent variables and dependent variables and used propensity score matching to eliminate self-selection problems. The two-stage least squares method was used to conduct another regression, and similar empirical results were obtained. Therefore, this article believes that the involvement of family members has a positive impact on technological innovation.

The enlightenment of the above research conclusions on the technological innovation of family-owned enterprises is mainly reflected in the following aspects. Firstly, this paper gives a preliminary answer to the technological innovation model selection problem in family-owned enterprises. As is well known, family-owned enterprises are faced with financing constraints and resource bottlenecks. It is necessary to choose an appropriate management model to enhance one's technological innovation ability. Secondly, the empirical results of this paper show that professional managers may have problems such as wasting resources and neglecting responsibilities. Therefore, family members' involvement is conducive to improving $R \& D$ performance and reducing unnecessary resource waste.

Finally, several limitations should be mentioned. Firstly, we only used R\&D investment and R\&D output to measure technological innovation, and could not capture the citation rate of patents. Thus, future researchers might take the patent citation rate as one of dependent variables. Secondly, the research results indicated that family members' involvement saves R\&D investment and increases R\&D output. However, this manuscript did not control R\&D investment before the regression of R\&D output. We encourage future researchers to study whether family members' involvement increase conversion rate of technological innovation under the premise of controlling R\&D investment. Thirdly, this paper only studied the influence of family member involvement on technological innovation, and did not study the influence mechanism between them. Future studies should focus on how family members' involvement affects technological innovation. 
Author Contributions: L.Z., L.L. and M.Z. conceptualized the research, designed the empirical framework; L.Z. and M.Z. managed the data collection initiatives and writing; L.Z. and L.L. conducted the empirical analysis and documented the findings. All authors have read and agreed to the published version of the manuscript.

Funding: This research received no external funding.

Conflicts of Interest: The authors declare no conflict of interest.

\section{References}

1. Ouchi, W. Theroy Z; China Machine Press: Beijing, China, 2013.

2. Anderson, R.C.; Reeb, D.M. Board Composition: Balancing Family Influence in S\&P 500 Firms. Adm. Sci. Q. 2004, 49, 209-237.

3. De Massis, A.; Frattini, F.; Lichtenthaler, U. Research on Technological Innovation in Family Firms: Present Debates and Future Directions. Fam. Bus. Rev. 2013, 26, 10-31. [CrossRef]

4. Chrisman, J.J.; Chua, J.H.; De Massis, A.; Frattini, F.; Wright, M. The Ability and Willingness Paradox in Family Firm Innovation. J. Prod. Innov. Manag. 2014, 32, 310-318. [CrossRef]

5. Matzler, K.; Veider, V.; Hautz, J.; Stadler, C. The Impact of Family Ownership, Management, and Governance on Innovation. J. Prod. Innov. Manag. 2015, 32, 319-333. [CrossRef]

6. Duran, P.; Kammerlander, N.; Essen, M.V.; Zelleger, T. Doing More with Less: Innovation Input and Output in Family Firms. Acad. Manag. J. 2016, 59, 1224-1264. [CrossRef]

7. Block, J.H. R\&D Investments in Family and Founder Firms: An Agency Perspective. J. Bus. Ventur. 2012, $27,248-265$.

8. Kotlar, J.; De Massis, A.; Frattini, F.; Bianchi, M.; Fang, H. Technology Acquisition in Family and Nonfamily Firms: A longitudinal Analysis of Spanish Manufacturing Firms. J. Prod. Innov. Manag. 2013, 30, 1073-1088. [CrossRef]

9. Urbinati, A.; Franzo, S.; De Massis, A.; Frattini, F. Innovation in Family Firms: A Review of Prior Studies and a Framework for Future Fesearch. In Revolution of Innovation Management; Brem, A., Viardot, E., Eds.; Palgrave Macmillan: London, UK, 2017.

10. Bending, D.; Nils Foege, J.; Endrib, S.; Brettel, M. The Effect of Family Involvement on Innovation Outcomes: The Moderating Role of Board Social Capital. J. Prod. Innov. Manag. 2020, 37, 249-272. [CrossRef]

11. Villalonga, B.; Amit, R. How Are U.S. Family Firms Controlled? Rev. Financ. Stud. 2009, 22, $3047-3091$. [CrossRef]

12. Jenson, M.C.; Meckling, W.H. Theory of Firm: Managerial Behavior, Agency Cost and Ownership Structure. J. Financ. Econ. 1976, 3, 305-360. [CrossRef]

13. Young, M.N.; Peng, M.W.; Ahlstrom, D.; Bruton, G.D.; Jiang, Y. Corporate Governance in Emerging Economics: A Review of the Principal-Principal Perspective. J. Manag. Stud. 2008, 45, 196-220. [CrossRef]

14. Dharwadkar, R.; George, G.; Brandes, P. Privatization in Emerging Economies: An Agency Theory Perspective. Acad. Manag. Rev. 2000, 25, 650-669. [CrossRef]

15. Chen, Y.Y.; Young, M.N. Cross-border Mergers and Acquisitions by Chinese Listed Companies: A Principal-principal Perspective. Asia Pac. J. Manag. 2010, 27, 523-539. [CrossRef]

16. Davis, J.H.; Schoorman, F.D.; Donaldson, L. Toward a Stewardship Theory of Management. Acad. Manag. Rev. 1997, 22, 20-47. [CrossRef]

17. Miller, D.; Le Breton-Miller, I.; Scholnick, B. Stewardship vs. Stagnation: An Empirical Comparison of Small Family and Non Family Business. J. Manag. Stud. 2008, 45, 51-78.

18. Eddleston, K.A.; Kellermanns, F.W. Destructive and Productive Family Relationship: A Stewardship Theory Perspective. J. Bus. Ventur. 2007, 22, 545-565. [CrossRef]

19. Wang, Y.S. "Separation" and "Unification" of Families, Households and Homes in Contemporary China. Soc. Sci. China 2016, 4, 91-110.

20. Simon, H.A. Altruism and Economics. Am. Econ. Rev. 1993, 83, 156-161.

21. Cai, H.; Li, H.; Park, A.; Zhou, L. Family Ties and Organizational Design: Evidence from Chinese Private Firms. Rev. Econ. Stat. 2013, 95, 850-867. [CrossRef]

22. Chrisman, J.J.; Chua, J.H.; Litz, R.A. Comparing the Agency Costs of Family and Non-Family Firms: Conceptual Issues and Exploratory Evidence. Entrep. Theory Pract. 2004, 28, 335-354. [CrossRef]

23. Tirole, J. The Theory of Corporate Finance; Princeton University Press: Princeton, NJ, USA, 2006. 
24. Burkart, M.; Panunzi, F.; Shieifer, A. Family Firm. J. Financ. 2003, 58, 2167-2201. [CrossRef]

25. Bauweraerts, J.; Colot, O. Exploring Nonlinear Effects of Family Involvement in the Board on Entrepreneurial Orientation. J. Bus. Res. 2017, 70, 185-192. [CrossRef]

26. Schulze, W.S.; Lubatkin, M.H.; Dino, R.N.; Buchholtz, A.K. Agency Relationships in Family Firms: Theory and Evidence. Organ. Sci. 2001, 12,99-116. [CrossRef]

27. Chua, J.H.; Chrisman, J.J.; Bergiel, E.B. An Agency Theoretic Analysis of the Professionalized Family Firm. Entrep. Theory Pract. 2017, 33, 355-372. [CrossRef]

28. Fei, X.T. Earthbound China; Shanghai People Publishing House: Shanghai, China, 2006.

29. Becker, G.S. Altruism in the Family and Selfishness in the Market Place. Lond. Sch. Econ. Political Sci. 1981, 48, 1-15. [CrossRef]

30. Dreu, C.K.W.D.; Kleef, G.A.V. The Influence of Power on the Information Search, Impression Formation, and Demands in Negotiation. J. Exp. Soc. Psychol. 2004, 40, 303-319. [CrossRef]

31. Zellweger, T.M.; Nason, R.S.; Nordqvisrt, M.; Brush, C.G. Why Do Family Firm Strive for Nonfinancial Goals? An Organizational Identity Perspective. Entrep. Theory Pract. 2017, 37, 229-248. [CrossRef]

32. He, X.G.; Li, J.; Mei, L. Kinship's Effects on Family Firms' Growth: An Empirical Study in China. China Ind. Econ. 2010, 1, 135-146.

33. Xu, J.J.; Lv, C.J. The Nature of Family Firms Executives and Earnings Quality: Evidence from Chinese Listed Companies. Manag. World 2011, 1, 112-120.

34. Jiang, F.X.; Zheng, X.J.; Cai, W.J. The "hold court from behind a screen" of controlling family and financial decisions of the firm. Manag. World 2017, 3, 125-145.

35. Gu, Z.H.; Wang, W.J. Kindred Relationship of Entrepreneurial Family Firm and Agency Cost. China J. Manag. 2014, 11, 1806-1817.

36. Yan, R.S.; Qian, X.Y.; Xiao, S.; Li, H. The Impact of the Heterogeneity of Family Involvement to R\&D Investment: The Moderating Effects of Marketization Degree and Political Connections. Entrep. Theory Pract. 2019, 11, 129-138.

37. Tian, X.; Wang, T.Y. Tolerance for Failure and Corporate Innovation. Rev. Financ. Stud. 2014, 27, $211-255$. [CrossRef]

38. Zhou, M.S.; Zhang, Q.J.; Yang, D. The Relationship between Innovation Investment and Stock Market Performance for GEM Firms: Based on the Company's Internal and External Perspective. Econ. Res. J. 2017, 52, 135-149.

39. Kong, D.M.; Xu, M.L.; Kong, G.W. Pay Gap and Firm Innovation in China. Econ. Res. J. 2017, 52, $144-157$.

40. Kou, Z.L.; Liu, X.Y. China Urban and Industrial Innovation Report 2017; Industrial Development Research Center of Fudan University: Shanghai, China, 2017.

41. Aghion, P.; Reenen, J.V.; Zingales, L. Innovation and Institutional Ownership. Am. Econ. Rev. 2013, 103, $277-304$. [CrossRef]

42. Lu, J.; Wang, W. Managerial Conservatism, Board Independence and Corporate Innovation. J. Corp. Financ. 2018, 48, 1-16. [CrossRef]

Publisher's Note: MDPI stays neutral with regard to jurisdictional claims in published maps and institutional affiliations.

(C) 2020 by the authors. Licensee MDPI, Basel, Switzerland. This article is an open access article distributed under the terms and conditions of the Creative Commons Attribution (CC BY) license (http://creativecommons.org/licenses/by/4.0/). 